\title{
Tri-Trophic Interactions within Potato Agro-Ecosystem, Qassim, KSA
}

\author{
Wafa A. Alkherb' ${ }^{1}$, Nagdy F. Abdel-Baky ${ }^{2}$, Mohammad A. Aldeghairi² \\ ${ }^{1}$ Department of Biology, College of Arts and Sciences in Buraydah, Qassim University, Buraydah, Saudi Arabia \\ ${ }^{2}$ Plant Production and Protection Department, College of Agriculture and Veterinary Medicine, Qassim University, Buraydah, Saudi Arabia \\ Email: *nafabde12005@yahoo.com
}

How to cite this paper: Alkherb, W.A., Abdel-Baky, N.F. and Aldeghairi, M.A. (2016) Tri-Trophic Interactions within Potato AgroEcosystem, Qassim, KSA. Agricultural Sciences, 7, 879-899.

http://dx.doi.org/10.4236/as.2016.712080

Received: August 29, 2016

Accepted: December 24, 2016

Published: December 27, 2016

Copyright $\odot 2016$ by authors and Scientific Research Publishing Inc. This work is licensed under the Creative Commons Attribution International License (CC BY 4.0).

http://creativecommons.org/licenses/by/4.0/

\section{Abstract}

Tri-trophic interactions between fertilizer applications, cotton aphid (Aphis gossypii Golver) and associated beneficial insects were studied to investigate direct and indirect effects of fertilizers (types and ratios) on potato plants under field and greenhouse conditions, A. gossypii and associated beneficial insects. Fertilizers regimes showed direct impacts on the potato plant phenology and indirect effects on both $A$. gossypii population and the associated beneficial insects. Our data indicated that potato plants had been influenced by fertilizer elements used within tri-trophic system comprising potato plants, cotton aphid, and certain associated beneficial insects. This demonstrates that a bottom-up interaction is robust and has a particular value in the attraction of beneficial insects towards the potato plant signals due to used fertilizers which can also have a function when plants are attacked by $A$. gossypii. Yet, flexibility in the use of fertilizers (as chemical cues) is conserved, and that may help beneficial insects to specifically focus on the odor of plants that carry potential plant hosts and avoid plants that are only attacked by non-hosts. These results support the still controversial notion that fertilizer elements, at least in part, help plants to serve as functional signals to attract the enemies of the harmful insects. These observations declare the benefits of the tri-trophic interactions as an ecological phenomenon in particular and the food chain in general. Additionally, this study may be useful to be used as a predictable model with the associated beneficial insects which may have key roles in overall aphid suppression or regulating its population. Impact of fertilizers on potato phenology characteristics and the cotton aphid population density seems to be variable based on types and ratios of the fertilizers. Interfacing the impact of natural enemies (plant-pest-natural enemies) through tri-trophic relationship within the food chain verified to be straightforward way of predicting on the impact of beneficial insects-guild on the cotton aphid population density.

\section{Keywords}

Tri-Trophic Interactions, Fertilizers, Potato Plants, Cotton Aphids, Beneficial Insects 


\section{Introduction}

Herbivores insects and associated natural enemies are considered one of the important basic components in the food chain and food web within any agricultural system. These insects are acting within their food levels in the food chain. The richness in insect natural enemies species and populations may help in playing vital effects in the stability of agro-ecosystems, even if their roles are severely affected by the organism's species in the trophic levels [1]. The relationship between plant species and herbivorous arthropod diversity has paid a significant attention by ecologists and entomologists. However, few studies have addressed the tri-trophic levels within a food web, such as, host plant, herbivore insects and their natural enemies in certain agro-ecosystems [2]. Accordingly, the tri-trophic interactions between plants, harmful insects and the associated natural enemies can afford an essential basis for planning an effective biological control method [3]. In addition, these findings could help to improve the effectiveness of the biological control agents when applied to suppress the herbivore populations. Study of trophic interactions among organisms has developed from simple plant- herbivore or prey-predator interactions to a more complex approach involving three or more trophic levels.

Habitat nature of herbivorous insects with even has whole or partial losses could lead a disruption into the biological interactions within a food chain, such as the natural pest control functions in the agro-ecosystems. These changes may cause a change of the community structure [4] There are two ecological phenomena occurred between organisms in the ecosystem. Firstly, it is the interaction of organisms with their environment, and the 2nd one is the interactions among organisms within the chain levels. These interactions could determine the composition and dynamics of communities [5]. Accordingly, it was believed that host plants have complex and intertwined relationship with herbivorous insects and other organisms [6]. Such ecological interactions could be occurred directly between two species and often have an indirect relation mediated by the third one of the same or another trophic level [7] [8]. In interaction trophic relationship within different trophic levels, it may be resulted an intra-guild interaction [9] [10], or a competition relationship [11]. Such these relationships may add complexity when studying the food webs.

Improving the plant quality or characteristics may be useful for improving insect predation and/or parasitism against herbivorous insects [12]. Sometimes some plant characteristics have various toxic or harmful elements against natural enemies [13]. Tri-trophic relationship between plant nutrition, insect and its natural enemy was identified [14] in order to understand these interactions, and the basic mechanism that occurred between the three components inside the food web and food chain. So, the final results may lead to address these interactions to better pest control methods and minimize pesticides use.

Relations regarding plant nutrition and insect feeding the tri-trophic relationships, are often a relationship between many energy producers (plant), through herbivores insect and predation (predatory insects), and/or parasitism [15]. Therefore, when it is 
cross- linked among three organisms that deal with nutrition levels called tri-trophic interactions. This means that the species in the food chain may play a specific role in such relationships "key species or/and keystone species" [16].

Aphids (Hemiptera:Aphididae) are groups of insects that have small soft-bodied called "plant louse" feed on plant parts by sucking out their juices [17]. Certain species of aphids are considered economic and destructive pests which have high degrees of specialization on plants [18]. In spite of, every host-plant has one or more aphid species that feed on it, however, management of most aphid species is almost be similar. In Qassim region, KSA, the cotton aphids, Aphis gossypii Glover, is considered the most important pest attacks vegetables and field crops and has many generations/year (Abdel-Baky, un-published data).

To arrange tri-trophic relationship between plant nutrition, herbivorous insects (aphids) and beneficial insect (coccinellids), information about each trophic level must be gained to understand how such these interactions could be occurred. Energy relationships between predator-prey are required for the achievement of bio-control strategies; however, these relationships are often ignored in many IPM programs [19]. Frequently, generalist predators are more abundant in annual crops, (field and vegetable crops), and have been figured out as important in controlling populations of the harmful insects [9]. However, effective use of the beneficial insects in regulation pest populations requires deep and full understanding the ecology and biology of predatory insects.

Because of the tri-trophic interaction studies support the viewpoint of agricultural ecologists which they are trying an early to increase biodiversity to restore the natural balance between organisms. Therefore, this study is aiming to highlighting on what is happening between organisms within the food web in the agricultural ecosystem.

\section{Materials and Methods}

This study was carried out in The Agricultural Research and Experimental Station (ARES) at the College of Agriculture and Veterinary Medicine, Qassim University (Saudi Arabia) during the spring of 2014. The following procedures were carried out.

\subsection{Plant, Fertilizer and Insects}

\subsubsection{The Host Plants (1st Trophic Level)}

Potato plants Solanum tuberosum (family: Solanaceae) was chosen as a host plant. To produce potted potatoes for our studies, the cultural practices recommended to commercial growers were followed. Sandy soil, mixed with compost as an organic matter, was used as growing media. Potato cuttings were transplanted into pots $(50 \mathrm{~cm}$ in diameter, $50 \mathrm{~cm}$ in depth), with two potato cuttings per pot. Potatoes require elevated and balanced levels of nitrogen and potassium for proper vegetative growth. Pots were divided into 5 groups, 4 of them were fertilized with four fertilizer regimes (varied based on types and ratios) as well as the check treatment (control) with compost only. Each group contains 10 pots (replicates)/fertilizer treatment. 


\subsubsection{Fertilizer Treatments (Nutrition Regimes)}

The compost was used with all treatments in greenhouse and open field plantations to provide good soil structure, source of other nutrition elements and keep the water around plant tubers and roots. This formulation is recommended by propagators to reduce leaf yellowing and increase longevity. Plants were fertilized twice in all developmental stages and watered as needed. The recommended fertilizer rates for pulse used in potatoes cultivation were added as granular fertilizer around the plant roots. Chemical fertilization began two weeks after plantation (with emerge of the 2nd true leaf). Plants and fertilizer regimes were performed in the open field and under greenhouse condition.

Depending on the fertilization levels four fertilizer regimes (treatments) were applied that consists of nitrogen, phosphorus and potassium, as well as, the control.

- 1st group: contains nitrogen only (N 46\%, Urea).

- 2nd group: contains nitrogen and potassium (N 20\%:K 52\% higher potassium element).

- 3rd group: contains nitrogen and phosphorus (N 20\%:P 52\% higher phosphorus element).

- 4th group: contains nitrogen, potassium and phosphorus by balanced ratios ( $\mathrm{N}$ 20\%:K 20: P 20\%).

- 5th group: the control (the check treatment which contains the compost only).

\subsubsection{Cotton Aphid (2nd Trophic Level)}

Aphids used in the study were obtained from the cotton aphids, Aphis gossypii Glover (Aphididae:Hemiptera) colony established originally with individuals collected from pepper plants that were grown in research greenhouses at ARES, Qassim University. Cotton aphid colony was maintained in the laboratory of Entomology at $25^{\circ} \mathrm{C}, 45 \%$ relative humidity $(\mathrm{RH})$, and under $11: 13 \mathrm{~h}(\mathrm{LD})$ photoperiod on potato plants and periodically augmented with individuals collected from naturally infested sweet pepper grown in experimental greenhouses at the university research station. We hypothesized that aphid population would increase with increasing host plant age. We manipulated host plant quality by manipulating fertilization across a different fertilization elements and ratios and determined its influence on aphid abundance.

When potato plants were approximately 4 weeks old, five apterous adults of $\mathrm{A}$. gos sypii (6 - 7 days old) were transferred with a camel's hair brush to the apical region of the plants in each pot either in greenhouse trail or in the open field. At weekly intervals, all aphids were subsequently visually counted on 15 potato plants (in random)/each treatment in both greenhouse and open field experiments. The experiments were terminated when plants completed their development, leaves completely transferred yellow colors and winged aphids were found away from the plants. In addition, population density of associated beneficial insects was estimated/fertilizer treatment as well as the check (control). The predators: prey (p:p) ratios were also counted. The beneficial: pest ratios for each variety were calculated [20] (Total numbers of harmful insect pests in a 
unit area/Total numbers of Predatory insects in the unit area).

In general, the predator: prey ratio can also be calculated by the following formula which $\mathrm{p}: \mathrm{p}=$ predator $(\mathrm{x})$ number in a sample unit/prey $(\mathrm{x})$ number in a sample unit. Visual examination samples were used to count aphids and associated predators in both potatoes. The p:p ratio of a predator with prey species was estimated by simply dividing the density of a predator with density of a prey species within weekly samples.

\subsection{Estimation of the Parasitism Rate of Cotton Aphids}

To estimate the aphid parasitoids on potato plants, random samples of the two aphid species were taken from each plant and kept in petri-dishes until the emergence of different parasitoid species. The parasitoids were identified and parasitism percentage was calculated.

\subsection{Statistical Analysis}

To reveal the apparent direct relationship between $A$. gossypii and natural enemies on potato which fertilized with different fertilizer types, statistical analysis was made by calculating the average, standard error (SE), and the variance between means (LSD). Aphid counts were analyzed using repeated-measures one-way ANOVA tests (Costat, 1990) with fertilization level and growth chamber as the main effects. Moreover, correlation coefficient was obtained to describe the strength of relationship among the studied variables. The susceptibility of potato plant to insect pests and their natural enemies were subjected to ANOVA (Costat, 1990). Tukey's honestly significant difference (Tukey's HSD) test was used to determine significance between pairs of mean values.

\section{Results}

\subsection{Effect of Fertilizer Regimes on Potato Phenology}

\subsubsection{Open Field Experiment}

It was clear that the organic material and mineral fertilizers influenced the characteristics of the potato plants. In this context, the height of potato main stem reached $42.4 \pm$ $4.54 \mathrm{~cm}$ with urea fertilizer ( $\mathrm{N}: 46 \%), 37.18 \pm 12.4 \mathrm{~cm}$ with a balanced fertilizer elements (N 20\%:P 20\%: K 20\%), $28.6 \pm 2.29 \mathrm{~cm}$ with NP fertilizer (N 14\%:P 54\%) and $29.1 \pm$ $2.32 \mathrm{~cm}$ with NK fertilizer ( $\mathrm{N} 14 \%$ : $\mathrm{K} 52 \%$ ). It is clear from Table 1 that the main stem of potato plants varies significantly depending on the fertilizers types and ratios used in this experiment. Regarding the number of potato leaves/plant, the number of potato leaves/plant was also affected by the type and rate of fertilizer. Number of leaves/plant reached $114.9 \pm 11.25,122.9 \pm 11.16,97.7 \pm 11.06$ and $85.2 \pm 10.9$ leaves/plant with (N: 46\%), (N 20\%:P 20\%:K $20 \%$ ), (N 14\%:P 54\%) and (N 14\%:K 52\%), respectively. Leaf area size recorded $\left(17.6 \pm 0.80 \mathrm{~cm}^{2}\right)$ (Table 1). Use of a balanced fertilizer elements, $(\mathrm{N}$ 20\%: P 20\%:K 20\%), recorded $(37.18 \pm 12.4 \mathrm{~cm})$ for the main stem height, $(122.9 \pm$ 11.16) for number of leaves/plant, and $\left(18.2 \pm 0.73 \mathrm{~cm}^{2}\right)$ for leaf area size. While there were no clear differences between the use of higher-phosphorus element (N 14\%:P $54 \%$ ), or higher-potassium element ( $14 \%: \mathrm{K} 52 \%$ ), separately (Table 1 ) on the potato 
phonological characters. However, all fertilizer treatments used showed significant differences in comparison with the control (Table 1).

\subsubsection{Greenhouse Treatment}

Urea fertilizer ( $\mathrm{N}: 46 \%$ ) contributed to increase main stem height to reach $42.1 \pm 4.6$ $\mathrm{cm}$ and number of plant leaflets (120.7 \pm 10.1 leaflet/plant), as well as increase potato leaf area size to reach $17.9 \pm 0.79 \mathrm{~cm}^{2}$ (Table 2). Balanced fertilizer elements (N 20\%:P 20\%:K 20\%), came next and recorded $37.1 \pm 5.7 \mathrm{~cm}$ for the main stem height, $119.1 \pm$ 1.05 for number of plant leaflets, and $18.7 \pm 0.67 \mathrm{~cm}^{2}$ for leaf area size. While there were no clear differences between the use of higher-phosphorus element (N 14\%:P 54\%), or higher-potassium element (N 14\%:K 52\%), separately (Table 2). However, all fertilizer treatments used showed significant differences in-between and when compared with the control (Table 2).

\subsection{Effect of Fertilizer Regimes on the Cotton Aphids, Aphis gossypii}

It seems that the use of fertilization to improve characteristics of potato plants caused an indirect impact on A. gossypii populations either when grown under field or greenhouse conditions (Figures 1-4). A. gossypii populations have been influenced by both plant age and infestation date by the aphid, as well as, fertilizers used. Additionally, it could be noticed that population densities of $A$. gossypii were very low in the beginning of the infestation, and then increased gradually till the end of the potato growing season. A. gossypii population density varied based on the type and rate of fertilizer elements.

Table 1. Effectiveness of different nutrients on certain phonological characters of potato plants (pen field condition).

\begin{tabular}{cccccccccc}
\hline & \multicolumn{4}{c}{ Fertilizers types and rates } & \multicolumn{3}{c}{ Statistical analysis } \\
\cline { 2 - 8 } Phenology of Potato plants & $\mathrm{N}$ & $\mathrm{N}(14 \%):$ & $\mathrm{N}(14 \%):$ & $\mathrm{N}(20 \%):$ & & \\
& $(46 \%)$ & $\mathrm{P}(54 \%)$ & $\mathrm{K}(52 \%)$ & $\mathrm{P}(20 \%): \mathrm{K}(20 \%)$ & Control & $\mathrm{F}$ & $\mathrm{LSD}$ & $\mathrm{P}$ \\
\hline Plant height $(\mathrm{cm})$ & $42.4 \pm 4.54 \mathrm{a}$ & $28.6 \pm 2.29 \mathrm{~b}$ & $29.1 \pm 2.32 \mathrm{~b}$ & $37.18 \pm 12.4 \mathrm{ab}$ & $14.8 \pm 0.48 \mathrm{c}$ & 11.84 & 8.9 & $0.000^{* * *}$ \\
No. Leaves/plant & $114.9 \pm 11.25 \mathrm{a}$ & $97.7 \pm 11.06 \mathrm{~b}$ & $85.2 \pm 10.9 \mathrm{~b}$ & $122.9 \pm 11.16 \mathrm{a}$ & $56.33 \pm 10.8 \mathrm{~b}$ & 4.15 & 34.5 & $0.001^{* *}$ \\
Leaf area size $\left(\mathrm{cm}^{2}\right)$ & $17.6 \pm 0.80 \mathrm{a}$ & $14.6 \pm 0.44 \mathrm{~b}$ & $14.6 \pm 0.25 \mathrm{~b}$ & $18.2 \pm 0.73 \mathrm{a}$ & $12.4 \pm 0.47 \mathrm{c}$ & 18.28 & 1.62 & $0.000^{* * *}$ \\
\hline
\end{tabular}

Table 2. Effectiveness of different nutrients on certain phonological characters of potato plants (greenhouse condition).

\begin{tabular}{|c|c|c|c|c|c|c|c|c|}
\hline \multirow[b]{2}{*}{$\begin{array}{l}\text { Phenology of } \\
\text { Potato plants }\end{array}$} & \multicolumn{5}{|c|}{ Fertilizers types and rates } & \multicolumn{3}{|c|}{ Statistical analysis } \\
\hline & $\mathrm{N}(46 \%)$ & $\begin{array}{l}\mathrm{N}(14 \%): \\
\mathrm{P}(54 \%)\end{array}$ & $\begin{array}{l}\mathrm{N}(14 \%): \\
\mathrm{K}(52 \%)\end{array}$ & $\begin{array}{c}\text { N (20\%): } \\
\text { P (20\%): K } \\
(20 \%)\end{array}$ & Control & $\mathrm{F}$ & LSD & $\mathrm{P}$ \\
\hline Plant height $(\mathrm{cm})$ & $42.1 \pm 4.6 \mathrm{a}$ & $29.1 \pm 2.19 b$ & $29.19 \pm 2.4 \mathrm{~b}$ & $37.1 \pm 5.7 \mathrm{a}$ & $14.6 \pm 0.51 \mathrm{c}$ & 13.36 & 8.76 & $0.000^{* * *}$ \\
\hline No. of leaves/plant & $120.7 \pm 10.1 \mathrm{a}$ & $89.6 \pm 10.67 c$ & $92.2 \pm 0.74 b$ & $119.1 \pm 1.05 \mathrm{ab}$ & $50.4 \pm 1.6 \mathrm{~d}$ & 7.3 & 35.52 & $0.000^{\star * *}$ \\
\hline Leaf area size $\left(\mathrm{cm}^{2}\right)$ & $17.9 \pm 0.79 \mathrm{a}$ & $14.5 \pm 0.32 \mathrm{~b}$ & $14.6 \pm 0.31 b$ & $18.7 \pm 0.67 \mathrm{a}$ & $12.6 \pm 0.72 c$ & 21.56 & 1.55 & $0.000^{* * *}$ \\
\hline
\end{tabular}




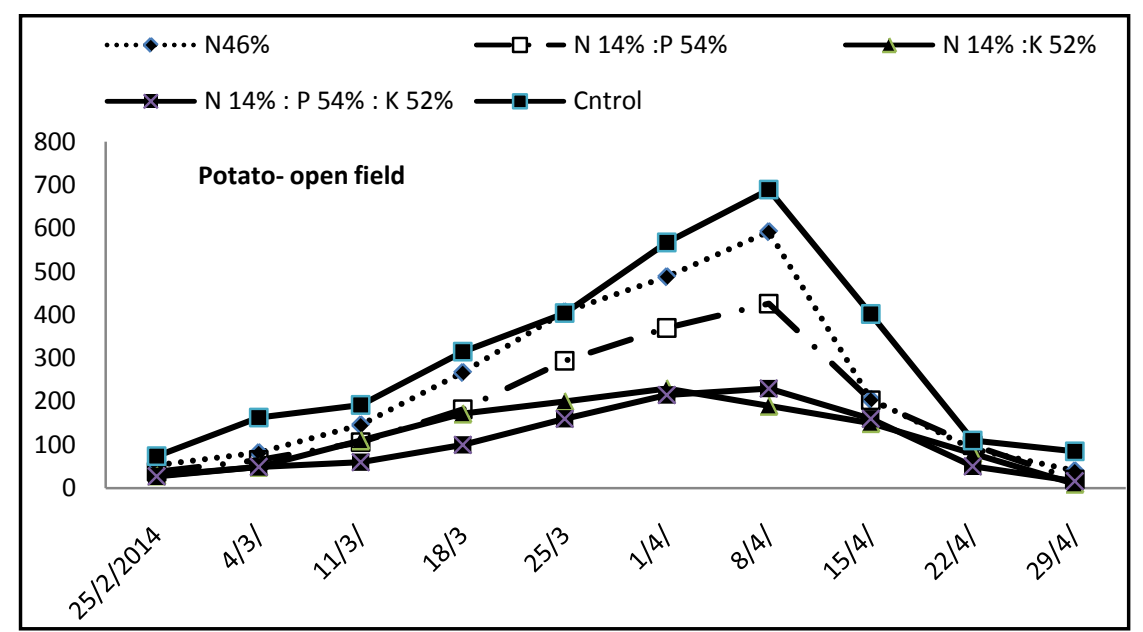

Figure 1. Effect of four fertilizers elements on the relative abundance of Aphis gossypii estimated by visual examination on potato plants under open field condition.

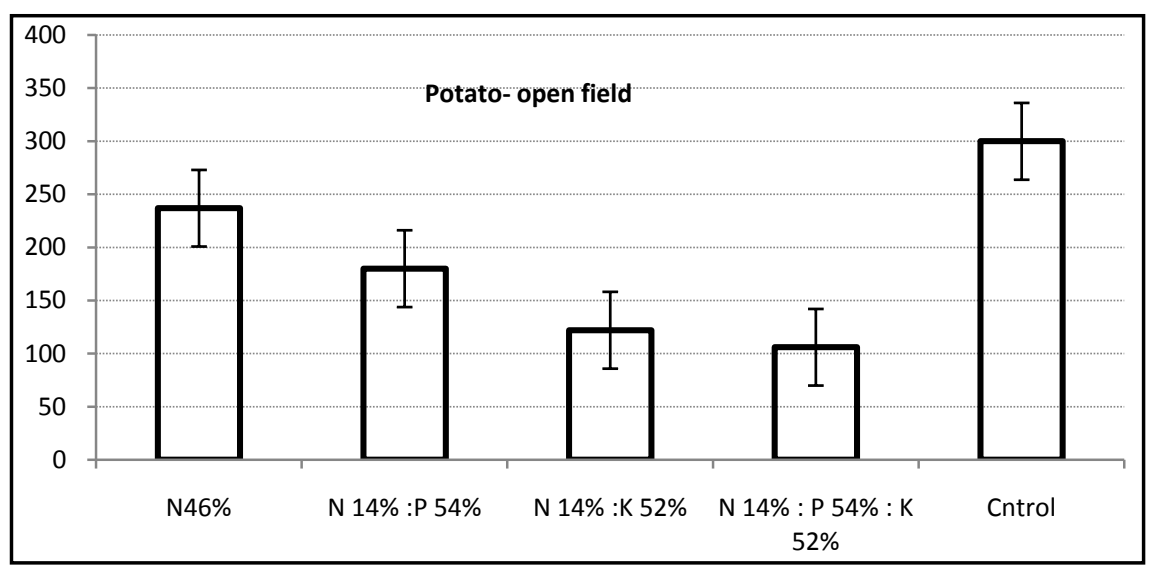

Figure 2. Effect of four fertilizers elements on the average number $( \pm \mathrm{SEM})$ of Aphis gossypii estimated by visual examination on potato plants under open field condition.

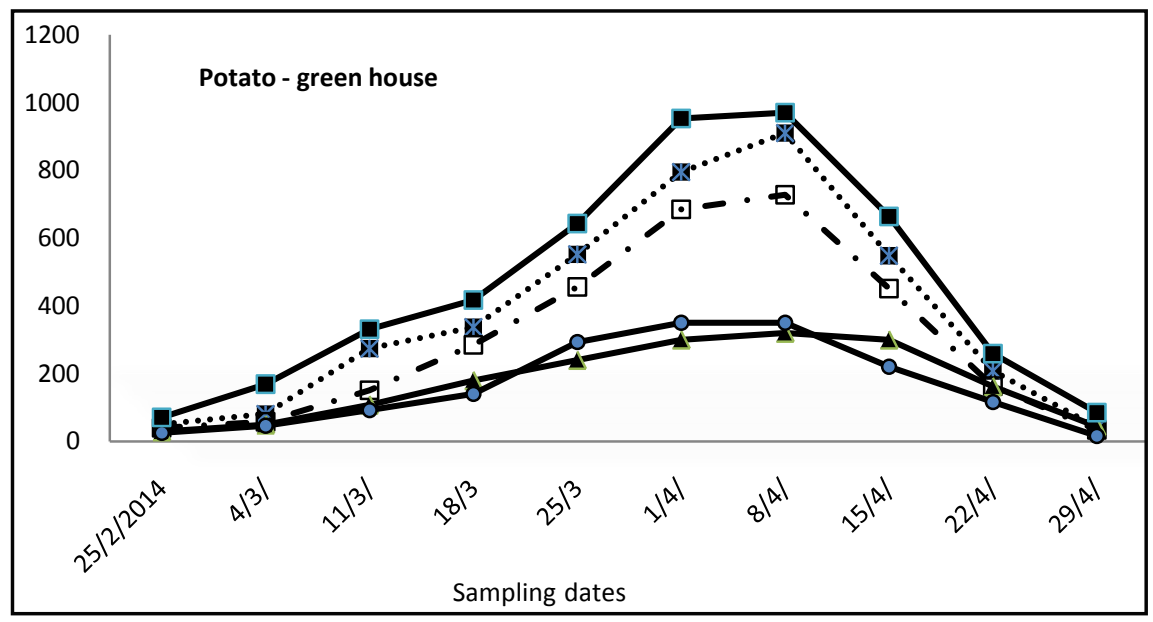

Figure 3. Effect of four fertilizers elements on the relative abundance of Aphis gossypii estimated by visual examination on potato plants under greenhouse condition. 


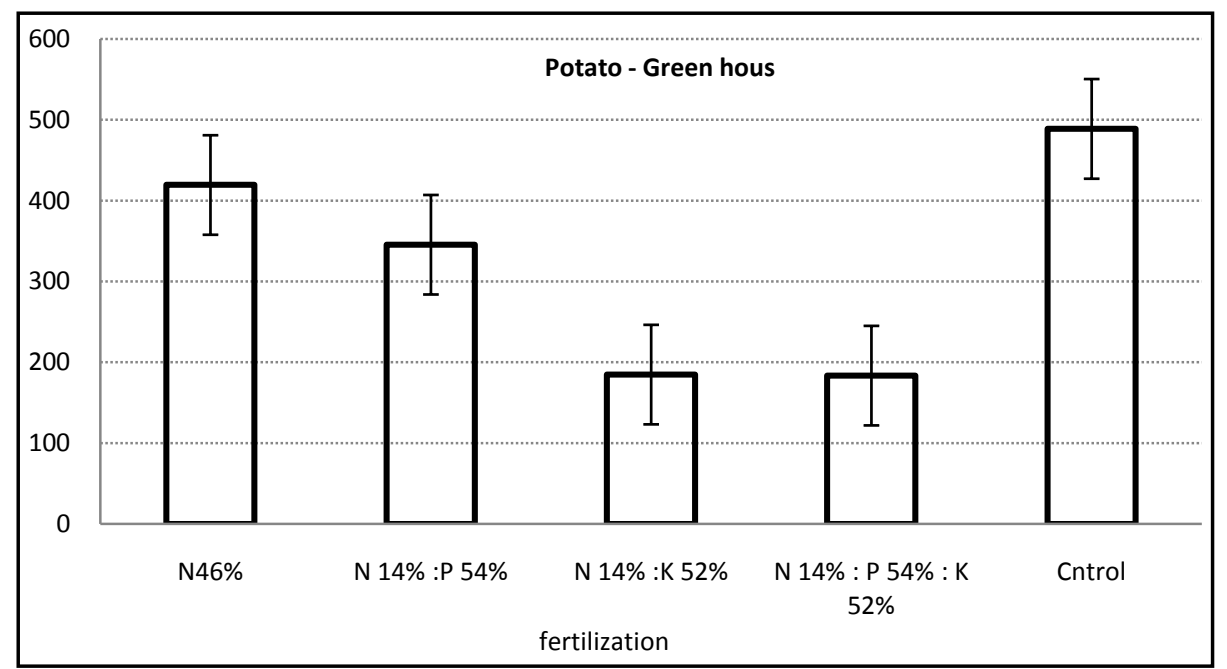

Figure 4. Effect of four fertilizers elements on the average number $( \pm \mathrm{SEM})$ of Aphis gossypii estimated by visual examination on potato plants under open field condition.

The cotton aphid population density had increased and reached its maximum numbers within the 7th week of plantation, then decreased gradually until the end of the season or until plant death (Figure 1). Moreover, the use of fertilizers had clear impacts on the cotton aphid populations and distributions within fertilizer treatments and growing seasons. In coronary, check treatment was a perfect one which had a great impact on $A$. gossypii population and recorded the highest population densities of $A$. gossypii, followed by a balanced fertilizer (N 14\%:P 54: K 52\%) and then a high-phosphorus fertilizer (N 14\%:P 54\%). While, Urea treatment (a high-nitrogen N: 46\%) and a high-potassium treatment (N 14\%:K 52\%) did not differed from each other and recorded a lowest population number of the cotton aphids.

In this respect, the average number of $A$. gossypii was higher $(237.0 \pm 6.3$ individuals/plant) with higher nitrogen level (46\%), followed by higher level of potassium (52\%) (N 14\%:K 52\%) (122.0 \pm 25.5 individuals/plant) (Table 2), however, A. gossypii numbers were not significantly influenced by fertilizers types. In comparison, use a highphosphorus fertilizer (N 14\%:P 54\%) and balanced fertilizer elements (N 20\%:P 20\%:K $20 \%$ ), cotton aphid populations' recorded $08.3 \pm 45.7$ and $106.7 \pm 25.4$ individuals/plant) (Figure 2).

Our results also showed that $A$. gossypii population densities varied based on fertilization rates (Figure 2). The highest colonization rates were recorded in control treatment (Compost only) which reached 33\% of the total aphid populations. Additionally, use of Urea (N 46\%) attracted about $29 \%$ of aphid populations, followed by a highphosphorus fertilizer (N 14\%:P $54 \%$ ) which recorded 17\% of cotton aphid population, then a high-potassium fertilizer (N 14\%:P $52 \%$ ) that allowed 12\% of aphid colonized on potato plants. Meanwhile, a balanced fertilizer of fertilization elements (N 20\%: P 20\%:K 20\%) recorded a lowest rate of settlement aphids on potato plants, reaching only $9 \%$ of the total (Figure 2). Same results were obtained under greenhouse conditions (Figure 3 \& Figure 4). 


\subsection{Effect of Fertilizer Regimes on Associated Beneficial Insects}

Natural enemies associated with the cotton aphid were also affected as a result of using the fertilizers. Fertilizer elements had an impact on the predatory insects and parasitoid that inhabit potato agro-ecosystem either in the open field or in the greenhouse (Table 3 \& Table 4). The balanced elements fertilizer (N 20\%:P 20\%:K 20\%), attracted the largest number of natural enemies. In open field plantation, natural enemies' population densities recorded $8.3 \pm 1.9$ individual/plant of Coccinella undecimpunctata, $8.2 \pm$ 1.2 individuals/plant of Hippodamia tredecimpunctata, $9.2 \pm 1.12$ individuals/plant of Chrysoperla carnea, and $9.6 \pm 1.48$ of Orius spp., $8.2 \pm 1.0$ individuals/plant of Syrphus corollae and $16.5 \pm 1.72$ individuals/plant of Aphid parasitoids (Table 3). Meanwhile, in greenhouse plantation, beneficial insects listed $6.16 \pm 0.97$ individual/plant of $C$. undecimpunctata, $5.33 \pm 1.05$ individuals/plant of $H$. 13-punctata, $8.16 \pm 1.41$ individuals/plant of Ch. carnea, and $7.75 \pm 1.40$ of Orius spp., $53.66 \pm 9.77$ individuals/plant of S. corollae and $14.1 \pm 1.50$ individuals/plant of aphid parasitoids (Table 4). The use of

Table 3. Impact of fertilizers on the cotton aphid and associated natural enemies inhabit potatoes in open fields.

\begin{tabular}{|c|c|c|c|c|c|c|c|c|}
\hline \multirow[b]{2}{*}{ Insects } & \multicolumn{5}{|c|}{ Fertilizers types and rates } & \multicolumn{3}{|c|}{ Statistical analysis } \\
\hline & $\begin{array}{c}\mathrm{N} \\
(46 \%)\end{array}$ & $\begin{array}{l}\text { N (14\%): } \\
\mathrm{P}(54 \%)\end{array}$ & $\begin{array}{c}\mathrm{N}(14 \%): \\
\mathrm{K}(52 \%)\end{array}$ & $\begin{array}{c}\text { N (20\%): } \\
\text { P (20\%):K (20\%) }\end{array}$ & Control & $\mathrm{F}$ & LSD & $\mathrm{P}$ \\
\hline Aphis gossypii & $237 \pm 6.3 \mathrm{ab}$ & $108.3 \pm 45.7 \mathrm{ab}$ & $122 \pm 25.5 b$ & $106.7 \pm 25.4 b$ & $300.1 \pm 68.3 a$ & 2.80 & 137.2 & $0.036^{*}$ \\
\hline Coccinella undecimpunctata & $1.15 \pm 0.35 \mathrm{bc}$ & $5.7 \pm 0.81 \mathrm{bc}$ & $6.2 \pm 0.67 \mathrm{ab}$ & $8.3 \pm 1.9 \mathrm{a}$ & $3.64 \pm 0.51 c$ & 6.14 & 2.16 & $0.0005^{\star * *}$ \\
\hline Hippodamia 13-punctata & $3.3 \pm 0.42 c$ & $4 \pm 0.51 \mathrm{bc}$ & $6.7 \pm 1.00 \mathrm{ab}$ & $8.2 \pm 1.2 \mathrm{a}$ & $3.8 \pm 0.54 c$ & 6.92 & 2.23 & $0.0002^{* * *}$ \\
\hline Chrysoperla carnea & $4.3 \pm 0.54 c$ & $5.7 \pm 0.83 \mathrm{bc}$ & $6.9 \pm 0.87 b$ & $9.2 \pm 1.12 \mathrm{a}$ & $3.7 \pm 0.35 c$ & 8.02 & 2.23 & $0.0001^{\star * *}$ \\
\hline Orius spp. & $3.8 \pm 0.45 c$ & $5.5 \pm 0.45 \mathrm{bc}$ & $6.4 \pm 0.87 b$ & $9.6 \pm 1.48 \mathrm{a}$ & $3.4 \pm 0.48 c$ & 9.22 & 2.37 & $0.000^{\star * *}$ \\
\hline Syrphus corolla & $5.0 \pm 0.93 b c$ & $5.9 \pm 0.51 \mathrm{abc}$ & $7.5 \pm 1.1 \mathrm{ab}$ & $8.2 \pm 1.00 \mathrm{a}$ & $4.3 \pm 045 c$ & 3.74 & 2.42 & $0.013^{\star *}$ \\
\hline Parasitism \% & $9 \pm 1.03 b c$ & $10.05 \pm 1.16 \mathrm{bc}$ & $11.5 \pm 0.9 b$ & $16.5 \pm 1.72 \mathrm{a}$ & $6.7 \pm 0.77 c$ & 9.55 & 3.37 & \\
\hline
\end{tabular}

$\mathrm{df}=4,45$.

Table 4. Impact of fertilizers on the cotton aphid and associated natural enemies inhabit potatoes in greenhouses.

\begin{tabular}{|c|c|c|c|c|c|c|c|c|}
\hline Insects & \multicolumn{5}{|c|}{ Fertilizers types and rates } & \multicolumn{3}{|c|}{ Statistical analysis } \\
\hline Aphis gossypii & $2577 \pm 736.3 \mathrm{ab}$ & $1484 \pm 424.3 \mathrm{abc}$ & $1079 \pm 273 \mathrm{bc}$ & $787 \pm 204 c$ & $2875 \pm 764.4 \mathrm{a}$ & 2.86 & 1027.5 & $0.031^{*}$ \\
\hline Coccinella undecimpunctata & $2.91 \pm 0.47 \mathrm{bc}$ & $4.58 \pm 0.62 \mathrm{ab}$ & $5.41 \pm 0.62 \mathrm{a}$ & $6.16 \pm 0.97 \mathrm{a}$ & $2.25 \pm 0.34 \mathrm{c}$ & 6.33 & 1.86 & $0.000^{* * *}$ \\
\hline Chrysoperla carnea & $4.83 \pm 0.71 \mathrm{bc}$ & $5.75 \pm 0.85 \mathrm{abc}$ & $7.25 \pm 1.14 \mathrm{ab}$ & $8.16 \pm 1.41 \mathrm{a}$ & $3.75 \pm 0.77 c$ & 2.99 & 2.92 & $0.02^{*}$ \\
\hline Orius spp. & $5.25 \pm 0.84 \mathrm{a}$ & $6.83 \pm 1.3 \mathrm{a}$ & $7.25 \pm 0.9 \mathrm{a}$ & $7.75 \pm 1.4 \mathrm{a}$ & $4.75 \pm 0.87 \mathrm{a}$ & 1.83 & 2.72 & $0.13 \mathrm{~ns}$ \\
\hline Syrphus corolla & $10.58 \pm 2.02 \mathrm{c}$ & $22.66 \pm 5.77 \mathrm{bc}$ & $31.5 \pm 8.05 b$ & $53.66 \pm 9.77 \mathrm{a}$ & $10.3 \pm 1.94 \mathrm{c}$ & 7.81 & 18.21 & $0.000^{* * *}$ \\
\hline Parasitism \% & $9.5 \pm 0.88 \mathrm{bc}$ & $9.9 \pm 0.65 b c$ & $10.66 \pm 0.8 b$ & $14.1 \pm 1.5 \mathrm{a}$ & $7.5 \pm 0.62 c$ & 6.6 & 2.6 & $0.002^{\star *}$ \\
\hline
\end{tabular}

$\mathrm{df}=4,45$. 
fertilizer with high-potassium element (N 14\%:K 52\%), the numbers of beneficial insects were relatively high in comparison with other fertilization regimes, as well as, with the check treatment. While, beneficial insects numbers were relatively lower with a balanced elements fertilizer regime (N 20\%:P 20\%:K 20\%), followed by a fertilize regime with high-phosphorus element (N 14\%:P 54\%). On the other hand, Urea fertilizer (N: 46\%) was less attractive to the beneficial insects (Table 3 and Table 4).

It is evident from Table 3 and Table 4 that natural enemies populations was higher in the open filed compared with greenhouses, with the exception of $S$. corollae which recorded a highest population density under greenhouse conditions compared to the open field. Numbers of each natural enemy differed significantly among fertilizer treatments and the control. Additionally, numbers differed between open field and greenhouse potatoes (Table 3 and Table 4).

\subsection{Interaction between Fertilizer, Plant Phenology and Cotton Aphid:}

\subsubsection{Relationship between Plant Main Stem Height and A. gossypii Populations}

The correlation coefficient values between fertilizers and main stem height and the cotton aphid population density are shown in Table 5 and Table 6. Data illustrate that there is a positive correlation coefficient relationship between the fertilizer with high-phosphorus element (N 14\%:P 54\%), plant phenology and $A$. gossypii. The statistical values expressed by $0.764 \pm 0.221(\mathrm{r} \pm \mathrm{SE}$ ), $9.611 \pm 2.862$ (slope $\mathrm{b} \pm \mathrm{SE}$ ), -30.21 ( $\mathrm{Y}$ Int "a") and 0.009 (P) for main stem height, No. of leaves and leaf area size in open field (Table 5). In the same context, Urea fertilizer (N: 46\%) listed a greater correlation coefficient relationship with both plant phenology and $A$. gossypii. The statistical values were expressed by $0.932 \pm 0.125(\mathrm{r} \pm \mathrm{SE}), 16.441 \pm 2.22$ (slope $\mathrm{b} \pm \mathrm{SE}$ ), -325.5 (Y Int "a") and $0.000(\mathrm{P})$ (Table 5). On the other hand, other fertilizer regimes and control had no significant correlation coefficient relationship as shown in Table 5 in respect of open field cultivation.

In greenhouse, the fertilizer with high-phosphorus element (N 14\%: $\mathrm{P}$ 54\%) and Urea fertilizer (N: 46\%) had great negative correlation coefficient relationship with

Table 5. Correlation coefficient values between some potato plant phonological characters and numbers of $A$. gossypii, in open field.

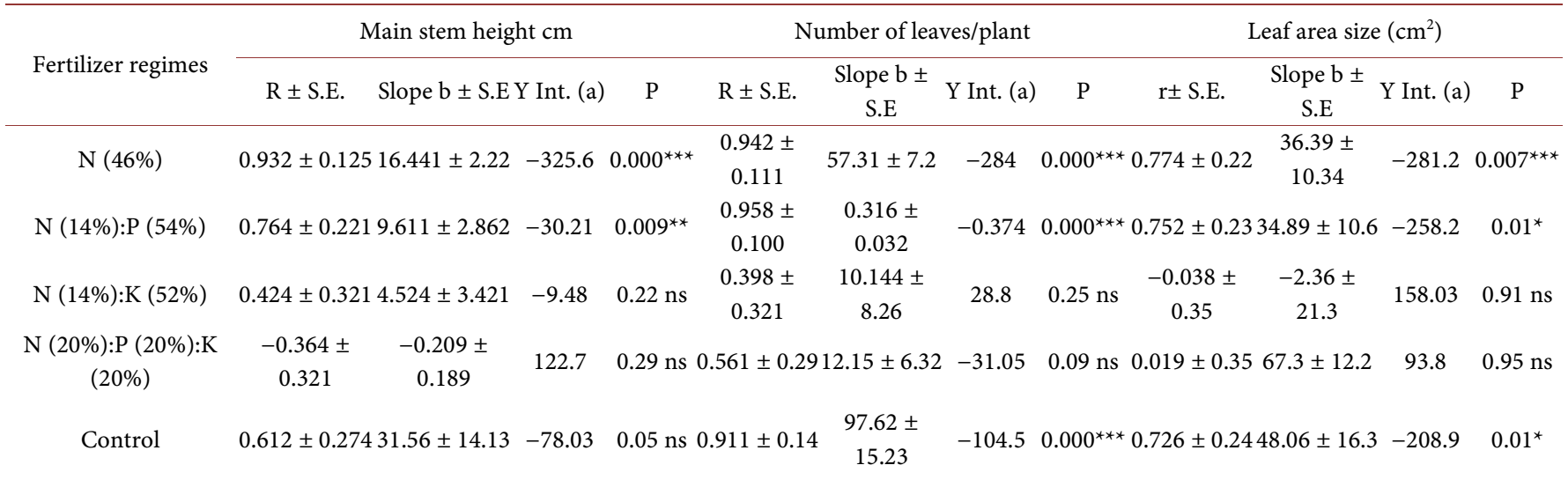


Table 6. Correlation coefficient values between some potato plant phonological characters and numbers of $A$. gossypii, in greenhouse.

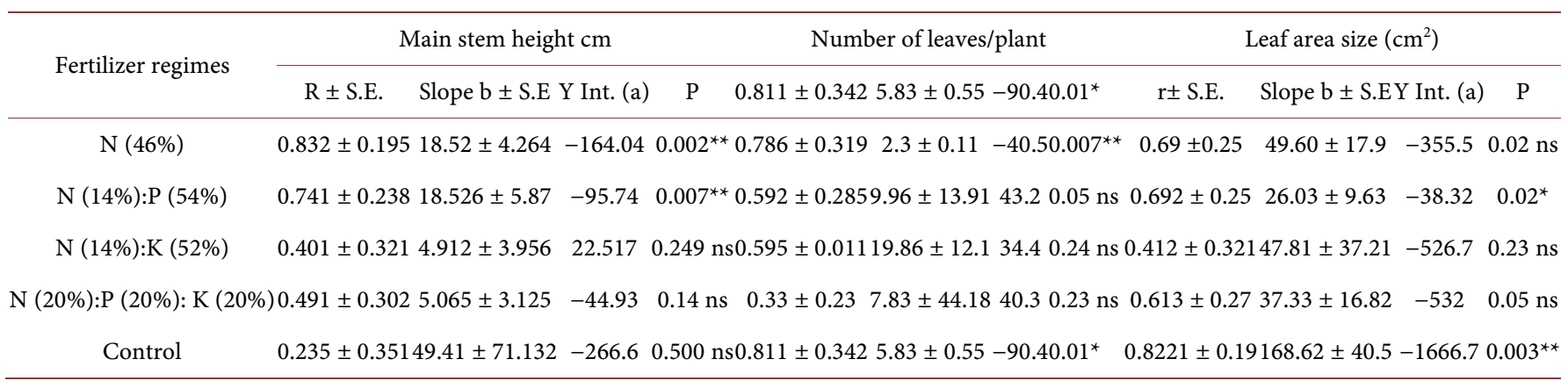

main stem height and A. gossypii. Correlation coefficient relationship were expressed as $0.741 \pm 0.238$ and $0.832 \pm 0.195(\mathrm{r} \pm \mathrm{SE}$ ) for stem height, $18.526 \pm 5.87$ and $18.52 \pm$ 4.264 (slope $\mathrm{b} \pm \mathrm{SE}$ ) for No. of leaves, -95.74 and -164.04 (Y Int “a”) and 0.007 and 0.002 (P) for the leaf area size (Table 6) for fertilizer (N 14\%:P 54\%) and Urea fertilizer, respectively. On the other hand, other fertilizer regimes and control had no significant correlation coefficient relationship as shown in Table 6.

\subsubsection{Relationship between Number of Leaves/Plant and Cotton Aphid}

The correlation coefficient with Urea fertilizer (N: 46\%); a higher-phosphorus element (N 14\%:P 54\%) and the check treatment (control) showed a strong and positive relationship with potato phenology and $A$. gossypii population density (Table 5) under open field condition. The statistical values expressed by $0.942 \pm 0.111 ; 0.958 \pm 0.100$ and $0.911 \pm 0.14(\mathrm{r} \pm \mathrm{SE}$ ), $57.32 \pm 7.2 ; 0.316 \pm 0.032$ and $97.62 \pm 15.23$ (slope $\mathrm{b} \pm \mathrm{SE}$ ), $-284.0 ;-0.374$ and -104.5 (Y Int "a") and 0.000; 0.000 and 0.000 (P) for (Urea N: 46\%); (N 14\%:P 54\%) and the check treatment, respectively (Table 5). Contrariwise, other fertilizer regimes showed non-significant correlation coefficient relationship in open field cultivation as shown in Table 5.

In the greenhouse, there are good correlation coefficient relationships with Urea fertilizer, higher-phosphorus element (N 14\%:P 54\%) and number of potato leaves (Table 6). The statistical values of the correlation coefficient relationship were expressed as $0.785 \pm 0.219$ and $0.711 \pm 0.241(\mathrm{r} \pm \mathrm{SE}$ ), $0.008 \pm 0.002$ and $72.87 \pm 25.056$ (slope $\mathrm{b} \pm$ SE), 3.812 and -414.2 (Y Int "a") and 0.007 and 0.01 (P) (Table 6) for a fertilizer with high-phosphorus element and a fertilizer contains a nitrogen only, respectively. However, other fertilizer regimes and control had no significant correlation coefficient relationship as shown in Table 6.

\subsubsection{Relationship between Leaf Area Size $\left(\mathrm{cm}^{2}\right)$ of Plant and Cotton Aphid}

Urea fertilizer (Urea N: 46\%) recorded a greater correlation coefficient relationship with both number of potato leaves and aphid population (Table 5) in open field cultivation. The statistical values expressed by $0.774 \pm 0.22(\mathrm{r} \pm \mathrm{SE}$ ), $36.39 \pm 10.34$ (slope $\mathrm{b} \pm$ SE), -281.2 (Y Int "a") and 0.007 (P) (Table 5). A higher-phosphorus element fertilizer (N 14\%:P 54\%) and control treatment showed a positive correlation coefficient relationship with both number of potato leaves and aphid population. Values of correlation 
reveals a simple positive relationship which expressed as $0.752 \pm 0.23$ and $0.726 \pm 0.24$ $(\mathrm{r} \pm \mathrm{SE}$ ), $34.89 \pm 10.6$ and $48.06 \pm 16.3$ (slope $\mathrm{b} \pm \mathrm{SE}$ ), -258.2 and -0.208 .9 (Y Int "a") and 0.01 and 0.01 (P), for (N 14\%:P 54\%) and the check treatment, respectively (Table 5). Contrariwise, other fertilizer regimes showed non-significant correlation coefficient relationship in open field cultivation as shown in Table 5.

In greenhouse cultivation, a higher-phosphorus element fertilizer (N 14\%:P 54\%) and control showed good correlation coefficient relationships with area leaf size $\left(\mathrm{cm}^{2}\right)$ and aphid population (Table 6). The statistical values of the correlation coefficient relationship were expressed as $0.692 \pm 0.25$ and $0.8221 \pm 0.19(\mathrm{r} \pm \mathrm{SE}), 26.03 \pm 9.63$ and $168.62 \pm 40.5$ (slope $\mathrm{b} \pm \mathrm{SE}$ ), -38.32 and -1666.7 (Y Int "a") and 0.02 and 0.003 (P) for a fertilizer with high-phosphorus element and the control, respectively. On the contrary, other fertilizer regimes showed non-significant correlation coefficient relationship as shown in Table (6).

\subsection{Interaction between Fertilizer, $A$. gossypii and Beneficial Insects}

\subsubsection{Coccinella Undecimpunctata}

A higher-potassium fertilizer, a balanced elements fertilizer and the control had good correlation coefficient relationships with $C$. undecimpunctata populations in the open field cultivation (Table $7(\mathrm{a})$ ). The correlation coefficient relationships values were expressed by $0.875 \pm 0.173,0.812 \pm 0.201$ and $0.764 \pm 0.222(\mathrm{r} \pm \mathrm{SE}), 0.024 \pm 0.004,0.0385$ \pm 0.009 and $0.005 \pm 0.001$ (slope $b \pm S E$ ), 3.2, 4.18 and 1.83 (Y Int "a") and 0.000, 0.004 and $0.01(\mathrm{P})$. In the other hand, a higher-potassium fertilizer had a strong relationship than other two mentioned treatments (Table 7(a)). Meanwhile, other fertilizer treatments had no significant relationship (Table 7(a)).

In greenhouse trial, all fertilizer treatments had strong and positive correlation coefficient relationships with $C$. undecimpunctata population, except the control treatment (Table 8(a)).

\subsubsection{Hippodamia Tredecimpunctata}

Table 7(a) refers to that all fertilizer treatments had a strong and positive correlation coefficient relationship except a fertilizer regimes contains a nitrogen only (Urea $\mathrm{N}$ : $46 \%)$ and the check treatment (control).

In greenhouse cultivation, only a higher-potassium fertilizer and balanced fertilizer elements showed strong relationships with $H$. tredecimpunctata (Table 8(a)). On the other hand, other fertilizer regimes had no effects on $H$. tredecimpunctata populations which represent a non-significant correlation coefficient relationship as shown in Table $8(a)$.

\subsubsection{Chrysoperla Carnea}

Only a higher-potassium fertilizer and a balanced elements fertilizer had a strong relationship with a predatory insect, $C h$. carnea which the correlation values were $0.781 \pm$ 0.22 and $0.816 \pm 0.20(\mathrm{r} \pm \mathrm{SE}$ ), $0.0201 \pm 0.012$ and $0.36 \pm 0.009$ (slope $\mathrm{b} \pm \mathrm{SE}$ ), 4.43 and 5.29 (Y Int "a"), 0.001 and $0.000(\mathrm{P})$, respectively (Table 8). In contrast, other fertilizer 
regimes showed non-significant correlation coefficient relationship as shown in Table $7(a)$.

In greenhouse, a higher-potassium fertilizer and Urea fertilizer had no correlation coefficient relationship with Ch. carnea population (Table 7(b)). While, other fertilizer treatments have had strong impacts and resulted in significant relationships with $C h$. carnea (Table 8(a)).

\subsubsection{Orius Spp.}

A higher-potassium fertilizer and a balanced elements fertilizer showed a strong relationship with a predatory insect, Orius spp. which their statistical values expressed as $0.803 \pm 0.210$ and $0.891 \pm 0.15(\mathrm{r} \pm \mathrm{SE}), 0.28 \pm 0.007$ and $0.042 \pm 0.009$ (slope $\mathrm{b} \pm \mathrm{SE}$ ), 2.92 and 4.02 (Y Int "a"), 0.005 and 0.000 (P), respectively (Table 7(b)). In contrast, other fertilizer regimes showed non-significant correlation coefficient relationship as shown in Table 7(b).

In greenhouse, all fertilizer treatments showed strong correlation coefficient relationship with Orius spp. populations, except the control treatment (Table 8(b)).

Table 7(a). Correlation coefficient values between numbers of $A$. gossypii and associated natural enemies that inhabit potato fields, under open field conditions.

\begin{tabular}{|c|c|c|c|c|c|c|c|c|c|c|c|c|}
\hline Fertilizer regimes & \multicolumn{4}{|c|}{ C. undecimpunctata } & \multicolumn{4}{|c|}{ H. tredecimpunctata } & \multicolumn{4}{|c|}{ Ch. carnea } \\
\hline N (14\%):P (54\%) & $0.593 \pm 0.284$ & $\begin{array}{c}0.0124 \pm \\
0.005\end{array}$ & 3.821 & $0.06 \mathrm{~ns}$ & $\begin{array}{c}0.742 \pm \\
0.231\end{array}$ & $0.009 \pm 0.002$ & 3.06 & $0.01^{\star}$ & $0.142 \pm 0.34$ & $40.002 \pm 0.006$ & 5.20 & $0.6 \mathrm{~ns}$ \\
\hline $\begin{array}{c}\mathrm{N}(20 \%): \mathrm{P}(20 \%): \mathrm{K} \\
(20 \%)\end{array}$ & $0.812 \pm 0.201$ & $\begin{array}{c}0.0385 \pm \\
0.009\end{array}$ & 4.18 & $0.004^{* *}$ & $\begin{array}{c}0.912 \pm \\
0.152\end{array}$ & $0.044 \pm 0.007$ & 3.6 & $0.000^{* * *}$ & $0.816 \pm 0.20$ & $0.036 \pm 0.009$ & 5.29 & $0.00^{* * *}$ \\
\hline Control & $0.764 \pm 0.2220$ & $0.005 \pm 0.001$ & 1.83 & $0.01 *$ & $0.321 \pm 0.33$ & $\begin{array}{c}0.0025 \pm \\
0.002\end{array}$ & 3.03 & $0.36 \mathrm{~ns}$ & $\begin{array}{c}0.241 \pm \\
0.341\end{array}$ & $0.001 \pm 0.00$ & 3.29 & $0.4 \mathrm{~ns}$ \\
\hline
\end{tabular}

Table 7(b). Correlation coefficient values between numbers of $A$. gossypii and associated natural enemies that inhabit potato fields, under open field conditions.

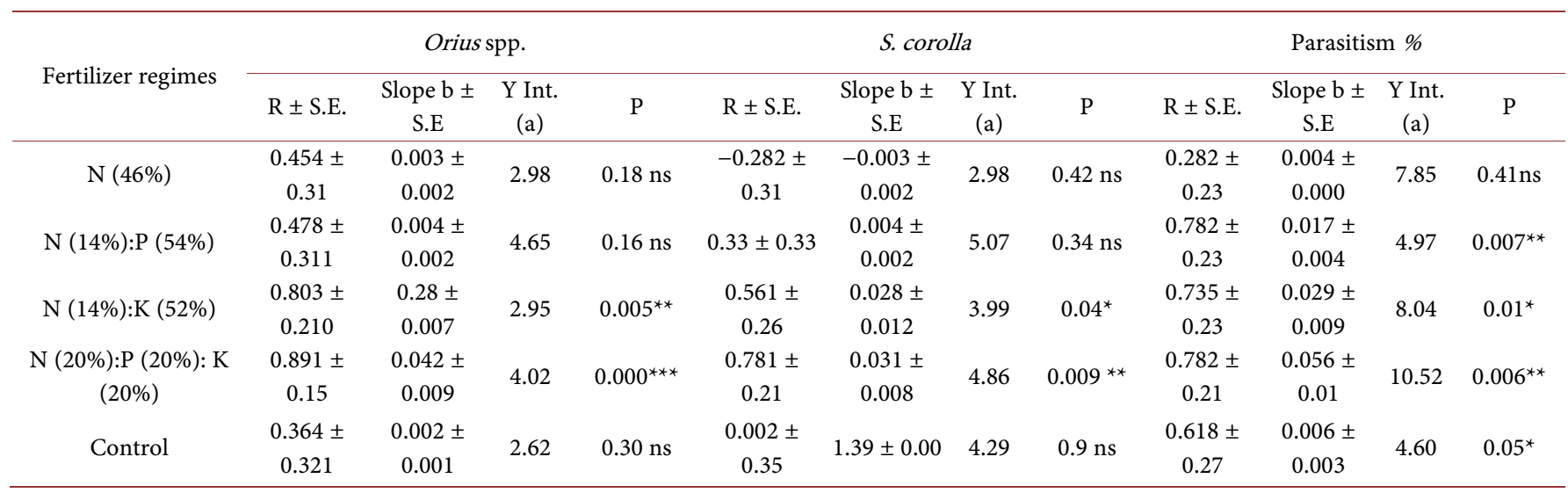


Table 8(a). Correlation coefficient values between numbers of $A$. gossypii and associated natural enemies that inhabit potato fields, under greenhouse conditions.

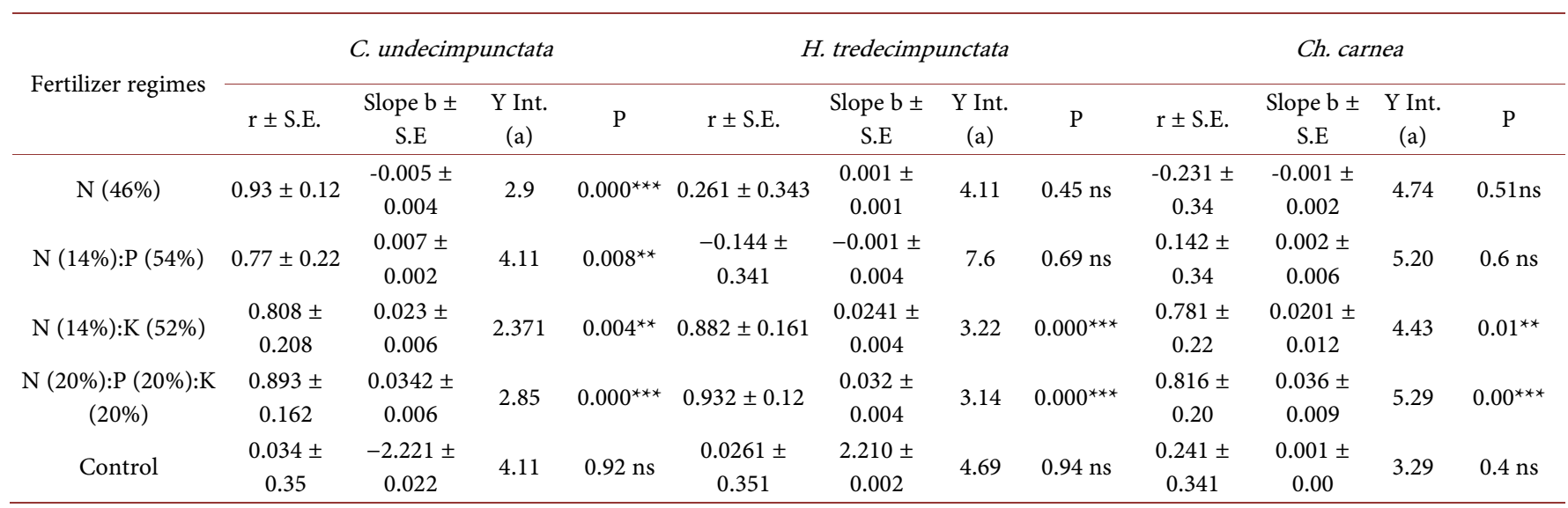

Table 8(b). Correlation coefficient values between numbers of $A$. gossypii and associated natural enemies that inhabit potato fields, under greenhouse conditions.

\begin{tabular}{|c|c|c|c|c|c|c|c|c|c|c|c|c|}
\hline Fertilizer regimes & $\mathrm{R} \pm$ S.E. & $\begin{array}{c}\text { Slope b } \pm \\
\text { S.E }\end{array}$ & $\begin{array}{l}\text { Y Int. } \\
\text { (a) }\end{array}$ & $\mathrm{P}$ & $\mathrm{R} \pm$ S.E. & $\begin{array}{c}\text { Slope b } \pm \\
\text { S.E }\end{array}$ & $\begin{array}{l}\text { Y Int. } \\
\text { (a) }\end{array}$ & $\mathrm{P}$ & $\mathrm{R} \pm$ S.E. & $\begin{array}{c}\text { Slope b } \pm \\
\text { S.E }\end{array}$ & $\begin{array}{l}\text { Y Int. } \\
\text { (a) }\end{array}$ & $\mathrm{P}$ \\
\hline $\mathrm{N}(14 \%): \mathrm{P}(54 \%)$ & $\begin{array}{c}0.478 \pm \\
0.311\end{array}$ & $\begin{array}{c}0.004 \pm \\
0.002\end{array}$ & 4.65 & $0.16 \mathrm{~ns}$ & $\begin{array}{c}0.712 \pm \\
0.25\end{array}$ & $\begin{array}{c}0.007 \pm \\
0.002\end{array}$ & 7.84 & $0.02^{*}$ & $\begin{array}{l}0.903 \pm \\
0.15\end{array}$ & $\begin{array}{c}0.015 \pm \\
0.002\end{array}$ & 4.41 & $0.000^{* * *}$ \\
\hline $\begin{array}{c}\mathrm{N}(20 \%): \mathrm{P}(20 \%): \mathrm{K} \\
(20 \%)\end{array}$ & $\begin{array}{c}0.891 \pm \\
0.15\end{array}$ & $\begin{array}{c}0.042 \pm \\
0.009\end{array}$ & 4.02 & $0.000^{* * *}$ & $\begin{array}{c}0.845 \pm \\
0.18\end{array}$ & $0.03 \pm 0.008$ & 4.42 & $0.000^{* * *}$ & $\begin{array}{c}0.876 \pm \\
0.172\end{array}$ & $\begin{array}{c}0.042 \pm \\
0.008\end{array}$ & 10.39 & $0.00^{* * *}$ \\
\hline Control & $\begin{array}{c}0.364 \pm \\
0.321\end{array}$ & $\begin{array}{c}0.002 \pm \\
0.001\end{array}$ & 2.62 & $0.30 \mathrm{~ns}$ & $\begin{array}{c}0.922 \pm \\
0.13\end{array}$ & $\begin{array}{c}0.006 \pm \\
0.001\end{array}$ & 2.02 & $0.000^{* * *}$ & $\begin{array}{c}0.814 \pm \\
0.20\end{array}$ & $\begin{array}{c}0.005 \pm \\
0.00\end{array}$ & 4.73 & $0.004^{* *}$ \\
\hline
\end{tabular}

\subsubsection{Syrphus Corollae Fabr}

Both of higher-potassium fertilizer and a balanced elements fertilizer resulted in a strong relationship with a predatory insect, Syrphus corollae and their statistical analysis values expressed as $0.561 \pm 0.26$ and $0.781 \pm 0.21(\mathrm{r} \pm \mathrm{SE}), 0.28 \pm 0.012$ and $0.031 \pm$ 0.008 (slope $\mathrm{b} \pm \mathrm{SE}$ ), 3.99 and 4.86 (Y Int "a"), 0.04 and 0.009 (P), respectively (Table $7(\mathrm{a})$ ). In contrast, other fertilizer regimes showed non-significant correlation coefficient relationship as shown in Table 7(b).

All fertilizer treatments showed strong correlation coefficient relationship with $S$. corollae populations, except Urea fertilizer in greenhouse cultivation (Table 8(b)).

\subsubsection{Aphid Parasitoid Populations, Aphidius colmani Stock}

Cotton aphid was parasitized by parasitoid wasp Aphidius colmani Stock, which mummies of the parasitoid were counted. In Table $7(\mathrm{~b})$, all fertilizer treatments had strong and positive correlation coefficient relationships with parasitism \%, except Urea fertilizer (N: 46\%) which had no significant relationship under field condition and greenhouse cultivations (Table 8(b)). 


\section{Discussion}

Potatoes agro-ecosystem is considered a complex of many trophic interactions, which potato plants are forming the basis of the food chains and webs. There are many aspects of organism's physiology; ecology and behavior in a specific ecosystem are governed by certain interactions among organisms that are from the same or/and another trophic level [21]. In this respect, our results showed that the correlation coefficient relationships between potato nutrition, potato characters, the cotton aphid and the beneficial insects in tri-trophic interaction of the food chain had very clear relationships [22]. These interactions between nutrients (fertilizers) and potato plants on one side and their associated insects on the other side are perhaps the most distinctive phenomenon of all tritrophic interaction relationships in an ecological niche [23]. Agro-ecosystems are characterized by the stability and lack of diversity almost, where increasing the diversity at a given trophic level can be weaken the effect of consumption on lower trophic levels [24]. Additionally, increasing the diversity can be weaken due to the increases in competition, or decreasing host availability, and changes in chemical defenses [25].

Previously, the tri-trophic interactions studies were affected directly or indirectly by many factors such as the co-evolution between organisms [26]. This hypothesis was preceded by an explicitly tri-trophic idea that specialized diets represent enemy free space for herbivores, because monophagous insects are better able to utilize chemical, morphological, and phonological attributes of their host plants to defend against beneficial insects [27].

Some plant fertilizers showed phosphates and enhance phosphate availability to plant may represent a possible mechanism of plant growth promotion under field conditions [28]. The incorporation of bio-fertilizers may also play major roles in improving soil fertility, yield attributing characters, with final yield [29] [30] [31]. Phosphorus and nitrogen are major nutrients and nitrogen is required for plants. Whereas most of phosphorus in Qassim soil is present in the form of insoluble phosphates and cannot be utilized by plants [32].

It is well known that the host plant acceptance by an any herbivorous insect is governed by a number of factors such as: 1) the herbivorous insect must be attracted and established on the host plant; 2) the insect needs to feed on the host and/or lay its eggs; and 3) the insect and immature must complete their development on the host [33]. Host plant morphological and chemical characters also influence the degree of association between the herbivore and its host plant that affect by fertilizer types and ratios as shown in the current study (Table 1 , Table 2, Table $5 \&$ Table 6). Therefore, the fertilizers that may be less negatively affected on the natural enemies may help in deciding the most suitable one. This method, use the fertilizer which has low negative effects on natural enemies, may help in IPM.

Plant nutrients by fertilizers which contain different nutritional elements may alter host plant morphological and physiological properties and so, it may affects directly or indirectly on the insect pest and natural enemies. Many ecological studies had con- 
ducted to determine effects of the farming systems and agriculture operations on insect fauna, where the underlying assumption being that a high abundance and diversity of predators enhances sustainability [34]. Populations of the beneficial insects had an indication value for environmental changes [35].

Response of $A$. gossypii to potato nutrient may lead to increase or decrease beneficial insect population densities by several ways. Cotton aphids may display number of anti-predator behaviors in response to natural enemies. There are many short-term describe cotton aphid responses to its natural enemy such as: 1) release an alarm pheromone [36] [37]; 2) shake the body vigorously while kicking at the parasitoid with the hind legs (Dixon 1958); 3) walking away from the threatened feeding site [38]; 4) dropping off the plant to avoid exposure [39] [40]; 5) clustering together to reduce predation risk by dilution effect [41]; and 6) selecting host plants and microhabitats free of predators [38]. Anti-predator responses may also be long-term responses such as: 7) ingesting toxic allelochemicals having deterrent or toxic effects on predators [42];8) enhancing the production of winged morphs, which may eventually avoid predators [43]; and 9) enhances the production of soldiers, which may eventually defend the colony [44] [45]. Among these tactics, dropping behavior is one of the most studied aphid anti-predator responses [27] [34] [46]-[52].

Additionally, the numerical response of cotton aphids to potato nutrition, suggest that the fertilizers used had different effects on potato plants [53]. According to [54] [55] cotton aphids are considered a highly polyphagous insect which feed on a wide range of host plants. Therefore, it is possible that aphids have mechanisms to tolerate or overcome plant defensive. Probably, the morpho-physiological variations among plants as a result of fertilizer treatments were sufficient to cause changes in aphids' population numbers. Similar results were also found in [56] study on the population growth of $A$. gossypii indifferent cotton cultivars.

Fertilizers can affect potato plant properties (i.e. morphologically and chemo-physiologically) and thus directly affect cotton aphid populations and indirectly on associated natural enemies (Table 3, Table 4 and Table 7(a) \& Table 7(b)). By affecting the foraging efficiency of cotton aphid natural enemies, such as predators and parasitoids, plants can affect the impact that those enemies have on cotton aphid populations and thus ultimately interfere with predator-prey or parasitoid-host dynamics [51] [57]. Parasitoids can increase their efficiency in host finding by learning plant-related cues (e.g. chemo-physiological characteristics) and temporarily specialize on available and profitable plants [58]. Cotton aphid incidence and its natural enemies in different fertilizers were presented also by [59]. Significant differences of the average number of cotton aphid and its natural enemies were found between fertilizers treatments used.

In 2003 and 2004 abundance of aphids was, respectively, 1.5 and 2.8 parasites which are 1.4 and 2.2 times higher in fertilized treatment [59]. Largest number of aphids was observed on manure fertilized cabbages in our research. This might suggest that fertilized plants may contain more of chemical substance than non-fertilized and also other plant related factors cause the increase of the activity and abundance of the aphids, since herbivorous insect species at the second trophic level have an important position 
in food webs since $A$. gossypii is phytophagous insect, and interactions within one trophic level may affect interactions at other higher trophic levels [60]. When weather change to dry, thus more soluble nitrogen found in fertilized plants than in non-fertilized and aphid population became more abundant [61]. On the other hand, fertilization with manure increases soil biological activity, improves water and air regime [62]. Furthermore, abundance of aphids was 3.3 (non-fertilized) and 4.4 (fertilized) times higher in 2003, respectively, which is 5.5 and 8.2 times higher in 2004 in covered plants compared with non-covered [59].

More parasitized aphids were found in manure-fertilized treatments in study [59], but in covered plants they get opposite results-more parasitized aphids we found in non-fertilized plants, maybe it was negative influence of covering on D. rapae to find aphids or to move.

Aphid-natural enemies' relationship, by visual examination, was in numerical increase with increase of plant characters and age, which could be explain by two factors. 1) It is possible field surveys overestimate the density of beneficial insects late in the growing season. The aphid natural enemies may remain on the plant for some time after ending the growing season, which means scouting data later in the growing season may represent partially cumulative counts of aphid natural enemy, rather than a time step cohort. 2) As aphid density increases, it is probable that natural enemies occurring in adjacent habitats will move into potato and cabbage fields to feed, so the natural enemy complex at the end of the growing season likely represents both resident and immigrant populations of these taxa.

In conclusion, fertilization of plants may affect directly abundance and diversity of herbivore via altered host plant quality and availability and indirectly. Interacting effects of features of the vegetation with host-beneficial insects systems could further alter more complex interactions in a multi trophic context of bottom-up effect. So, it can be inferred that the cotton aphid was suitable for the growth, development and reproduction of natural enemies that inhabiting potato plants. Aphid species significantly affected the biology and performance of natural enemies. A. gossypii, was the most suitable prey. Moreover, as suggested by the different researchers cited above, not only the food prey but also the host plants of prey affect the natural enemies' performance; therefore, it is important that the biological traits of natural enemies be considered in tri-trophic interactions. Thus, further investigation is needed.

\section{Conclusion}

This study shows that plant-mediated signaling is affected by the fertilizer elements in the tri-trophic system. This demonstrates that a particular interaction is robust and that the attraction of natural enemies of herbivores to plant signals can also function when plants are attacked by insect pests. Accordingly, this study indicates the benefits of the tri-trophic interactions as an ecological phenomenon in particular and the food chain in general. The impact of natural enemies (plant-pest-predator) through tri-trophic relationship within the food chain proved to be a straightforward way of predicting the 
impact of the natural enemies on the reduction of any harmful insect.

\section{Acknowledgements}

This work was funded by the Scientific Deanship of Qassim University, KSA.

\section{References}

[1] Cardinale, B.J.L., et al. (2006) Effects of Biodiversity on the Functioning of Trophic Groups and Ecosystems. Nature, 26, 989-992.

[2] Bronstein, J.L. (1998) The Contribution of Ant-Plant Protection Studies to Our Understanding of Mutualism. Biotropica, 30, 150-161.

https://doi.org/10.1111/j.1744-7429.1998.tb00050.x

[3] Del-Claro, K. (2004) Multitrophic Relationships, Conditional Mutualisms, and the Study of Interaction Biodiversity in Tropical Savannas. Neotropical Entomology, 33, 665-672. https://doi.org/10.1590/S1519-566X2004000600002

[4] Rosenheim, J.A., Kaya, H.K., Ehler, L.E., Marois, J.J. and Jafee, B.A. (1995) Intra-Guild Predation among Biological Control Agents: Theory and Evidence. Biological Control, 5, 303-355. https://doi.org/10.1006/bcon.1995.1038

[5] Rosenheim, J.A. (1998) Higher-Order Predators and the Regulation of Insect Herbivore Populations. Annual Review of Entomology, 43, 421-447.

https://doi.org/10.1146/annurev.ento.43.1.421

[6] Kaplan, I., Mcart, S.H. and Thaler, J.S. (2014) Plant Defenses and Predation Risk Differentially Shape Patterns of Consumption, Growth, and Digestive Efficiency in a Guild of Leaf-Chewing Insects. PLoS ONE, 9, e93714. https://doi.org/10.1371/journal.pone.0093714

[7] Thaler, J.S., Olsen, E.L. and Kaplan, I. (2015) Jasmonate-Induced Plant Defenses and Prey Availability Impact the Preference and Performance of an Omnivorous Stink Bug, Podisus maculiventris. Arthropod-Plant Interactions, 9, 141-148. https://doi.org/10.1007/s11829-015-9357-0

[8] Agrawal, A.A. (2000) Mechanisms, Ecological Consequences and Agricultural Implications of Tri-Trophic Interactions. Current Opinion in Plant Biology, 3, 329-335. https://doi.org/10.1016/S1369-5266(00)00089-3

[9] Dyer, L. and Letourneau, D. (1999) Relative Strengths of Top-Down and Bottom-Up Forces in a Tropical Forest Community. Oecologia, 119, 265-274. https://doi.org/10.1007/s004420050785

[10] Blackman, R.L. and Eastop, V.F. (2000) Aphids on the World's Crops: An Identification and Information Guide. John Wiley and Sons, Ltd., Chichester.

[11] Singh, A., et al. (2014) Plant Genetic Variation Mediates an Indirect Ecological Effect between Belowground Earthworms and Aboveground Aphids. BMC Ecology, 14, 25.

[12] Gao, F., Chen, F. and Ge, F. (2010) Elevated $\mathrm{CO}_{2}$ Lessens Predation of Chrysopa sinica on Aphis gossypii. Entomol. Entomologia Experimentalis et Applicata, 135, 135-140. https://doi.org/10.1111/j.1570-7458.2010.00979.x

[13] Grez, A.A. and González, R.H. (1995) Resource Concentration Hypothesis: Effect of Host Plant Patch Size on Density of Herbivorous Insects. Oecologia, 103, 471-474. https://doi.org/10.1007/BF00328685

[14] Rautapää, J. (1977) Evaluation of Predator: Prey Ratio Using Chrysopa carnea Steph in Control of Rophalosiphum padi(L.). Annales Agriculturae Fenniae, 16, 103-107.

[15] Poppy, G.M. (1997) Tritrophic Interactions: Improving Ecological Understanding and Bio- 
logical Control? Endeavour, 21, 61-65. https://doi.org/10.1016/S0160-9327(97)01042-9

[16] Moran, P.J. and Thompson, G.A. (2001) Molecular Responses to Aphid Feeding in Arabidopsis in Relation to Plant Defense Pathways. Plant Physiology, 125, 1074-1085. https://doi.org/10.1104/pp.125.2.1074

[17] Schoen1y, K., Beaver, R.A. and Heumier, T.A. (1991) On the Trophic Relations of Insects: A Food Web Approach. American Naturalist, 137, 597-638. https://doi.org/10.1086/285185

[18] Polis, G.A. and Strong, D.R. (1996) Food Web Complexity and Community Dynamics. American Naturalist, 147, 813-846. https://doi.org/10.1086/285880

[19] Hunter, M.D. (2003) Effects of Plant Quality on the Population Ecology of Parasitoids. Agricultural and Forest Entomology, 5, 1-8. https://doi.org/10.1046/j.1461-9563.2003.00168.x

[20] Winemiller, K. (1996) Factors Driving Temporal and Spatial Variation in Aquatic Food Webs. In: Polis, G.A. and Winemiller, K.O., Eds., Food Webs. Integration of Patterns and Dynamics, Chapman \& Hall, New York, 298-312. https://doi.org/10.1007/978-1-4615-7007-3_29

[21] Bowers, W.S., Nishino, C., Montgomery, M.E., Nault, L.R. and Nielson, M.W. (1977) Sesquiterpene Progenitor, Germacrene A: An Alarm Pheromone in Aphids. Science, 196, 680681. https://doi.org/10.1126/science.558651

[22] Verma, S.C., Ladha, J.K. and Tripathi, A.K. (2001) Evaluation of Plant Growth Promoting and Colonization Ability of Endophytic Diazotrophs from Deep Water Rice. Journal of Biotechnology, 91, 127-141. https://doi.org/10.1016/S0168-1656(01)00333-9

[23] Subashini, H.D., Malarvannan, S. and Kumar, P. (2007) Effect of Biofertilizers (N-Fixers) on Yield of Rice Cultivars in Pondicherry, India. Asian Journal of Agricultural Research, 1, 146-150. https://doi.org/10.3923/ajar.2007.146.150

[24] Kachroo, D. and Razdan, R. (2006) Growth, Nutrient Uptake and Yield of Wheat (Triticum aestivum) as Influenced by Biofertilizers and Nitrogen. Indian Journal of Agronomy, 51, 37-39.

[25] Son, T.N., Thu, V.V., Duong, V.C. and Hiraoka, H. (2007) Effect of Organic and Bio-Fertilizer on Soybean and Rice Under Rice Based Cropping System. Japan International Research Center for Agricultural Sciences, Tsukuba.

[26] Pradhan, N. and Sukla, L.B. (2005) Solubilization of Inorganic Phosphate by Fungi Isolated from Agriculture Soil. African Journal of Biotechnology, 5, 850-854.

[27] Schoonhoven, L.M., van Loon, J.J.A. and Dicke, M. (2005) Insect Plant Biology. Oxford University Press, Oxford, 421 p.

[28] Kromp, B. (1999) Carabid Beetles in Sustainable Agriculture: A Review on Pest Control Efficacy, Cultivation Impacts and Enhancement. Agriculture, Ecosystems \& Environment, 74, 187-228. https://doi.org/10.1016/S0167-8809(99)00037-7

[29] Nechols, J.R. and Obrycki, J.J. (1989) Comparative Behavioural and Ecological Studies in Relation to Biological Control: An Overview. Journal of the Kansas Entomological Society, 62, 146-147.

[30] Bowers, W.S., Nault, L.R., Webb, R.E. and Dutky, S.R. (1972) Aphidalarm Pheromone: Isolation, Identification, Synthesis. Science, 177, 1121-1122. https://doi.org/10.1126/science.177.4054.1121

[31] Nault, L.R., Montgomery, M.E. and Bowers, W.S. (1976) Ant-Aphid Association: Role of Aphid Alarm Pheromone. Science, 192, 1349-1351. https://doi.org/10.1126/science.1273595

[32] Hopkins, G.W. and Dixon, A.F.G. (1997) Enemy-Free Space and the Feeding Niche of an Aphid. Ecological Entomology, 22, 271-274. 
https://doi.org/10.1046/j.1365-2311.1997.00075.x

[33] Dill, L.M., Fraser, A. and Roitberg, B.D. (1990) The Economics of Escape Behaviour in the Pea Aphid, Acyrthosiphon pisum. Oecologia, 83, 473-478. https://doi.org/10.1007/BF00317197

[34] Soler, R., Bezemer, T.M. and Harvey, J.A. (2013) Chemical Ecology of Insect Parasitoids in a Multitrophic Above- and Below- Ground Context. In: Wajnberg, E. and Colazza, S., Eds., Chemical Ecology of Insect Parasitoids, John Wiley \& Sons, Ltd., Chichester, 64-85. https://doi.org/10.1002/9781118409589.ch4

[35] Chau, A. and Mackauer, M. (1997) Dropping of Pea Aphids from Feeding Site: A Consequence of Parasitism by the Wasp, Monoctonus paulensis. Entomologia Experimentalis et Applicata, 83, 247-252. https://doi.org/10.1046/j.1570-7458.1997.00179.x

[36] Turchin, P. and Kareiva, P. (1989) Aggregation in Aphis Varians: An Effective Strategy for Reducing Predation Risk. Ecology, 70, 1008-1016. https://doi.org/10.2307/1941369

[37] Szentesi, A. and Wink, M. (1991) Fate of Quinolizidine Alkaloids through Three Trophic Levels: Laburnum anagyroides (Leguminosae) and Associated Organisms. Journal of Chemical Ecology, 17, 557-1574. https://doi.org/10.1007/BF00984688

[38] Weisser, W.W., Braendle, C. and Minoretti, N. (1999) Predator Induced Morphological Shift in the Pea Aphid. Proceedings of the Royal Society of London, Series B, 266, 11751181. https://doi.org/10.1098/rspb.1999.0760

[39] Aoki, S., Kurosu, U., Shibao, H., Yamane, S. and Fukatsu, T. (1998) Defense by a Few First-Instar Nymphs in the Closed Gall of Dinipponaphis autumna (Homoptera, Aphididae, Hormaphidinae). Journal of Ethology, 16, 91-96. https://doi.org/10.1007/BF02769287

[40] Foster, W.A. and Rhoden, P.K. (1998) Soldiers Effectively Defend Aphid Colonies against Predators in the Field. Animal Behaviour, 55, 761-765. https://doi.org/10.1006/anbe.1997.0664

[41] Stadler, B. and Mackauer, M. (1996) Influence of Plant Quality on Interactions between the Aphid Parasitoid Ephedrus californicus Baker (Hymenoptera: Aphidiidae) and Its Host, Acyrthosiphon pisum (Harris) (Homoptera: Aphididae). Canadian Entomologist, 128, 27 39. https://doi.org/10.4039/Ent12827-1

[42] Stadler, B., Weisser, W. and Houston, A. (1994) Defense Reactions in Aphids: The Influence of the State and Future Reproductive Success. Journal of Animal Ecology, 63, 419-430. https://doi.org/10.2307/5559

[43] Andrade, M.C.B. and Roitberg, B.D. (1995) Rapid Response to Intraclonal Selection in the Pea Aphid (Acyrthosiphon pisum). Evolutionary Ecology, 9, 397-410. https://doi.org/10.1007/BF01237762

[44] Dicke, M. (2009) Behavioural and Community Ecology of Plants That Cry for Help. Plant, Cell \& Environment, 32, 654-665. https://doi.org/10.1111/j.1365-3040.2008.01913.x

[45] Losey, J.E. and Denno, R.F. (1998) The Escape Response of Pea Aphids to Foliar-Foraging Predators: Factors Affecting Dropping Behaviour. Ecological Entomology, 23, 53-61. https://doi.org/10.1046/j.1365-2311.1998.00102.x

[46] Losey, J.E. and Denno, R.F. (1998) Interspecific Variation in the Escape Responses of Aphids: Effect on Risk of Predation from Foliar-Foraging and Ground-Foraging Predators. Oecologia, 115, 245-252. https://doi.org/10.1007/s004420050513

[47] Abdel-Baky, N.F., Abou El-Naga, A.M., Miller, T.A., El-Adl, M.A. and Ghanim, A.A. (1997) Determination the Economic Decision Making Levels of Cotton Field, Aphis gossypii at Different Growth Stages of Cotton Crop. Proceedings of 1 st National Conference of Applied Using of Natural Enemies for Controlling Insect and Mite Pests, Mansoura, 4-5 
March 1997.

[48] Agarwala, B.K. and Ray, C.P. (2013) Host Races of the Cotton Aphid, Aphis gossypii, in Asexual Populations from Wild Plants of Taro and Brinjal. Journal of Insect Science, 13, 113. https://doi.org/10.1673/031.013.3401

[49] Fernandes, A.M.V., Farias, A.M.I., Soares, M.M.M. and Vasconcelos, S.D. (2001) Desenvolvimento do pulgão Aphis gossypii Glover (Hemiptera: Aphididae) em três cultivares do algodão herbáceo Gossypium hirsutum L. r. latifolium Hutch. Neotropical Entomology, 30, 467-470. https://doi.org/10.1590/S1519-566X2001000300021

[50] Dicke, M. and Vet, L.E.M. (1999) Plant-Carnivore Interactions: Evolutionary and Ecological Consequences for Plant, Herbivore and Carnivore. In: Olff, H., Brown, V.K. and Drent, R.H., Eds., Herbivores between Plants and Predators, Blackwell Science, London, 483-520.

[51] Geervliet, J.B.F., Verdel, M.S.W., Snellen, H., Schaub, J., Dicke, M. and Vet, L.E.M. (2000) Coexistence and Niche Segregation by Field Populations of the Parasitoids Cotesia glomerata and C. rubecula in the Netherlands: Predicting Field Performance from Laboratory Data. Oecologia, 124, 55-63. https://doi.org/10.1007/s004420050024

[52] Duchovskienė, L. and Raudonis, L. (2008) Seasonal Abundance of Brevicoryne brassicae L. and Diaeretiella rapae (M'Intosh) under Different Cabbage Growing Systems. Ekologija, 54, 260-264.

[53] Groot, A.T. and Dicke, M. (2002) Insect-Resistant Transgenic Plants in a Multi-Trophic Context. The Plant Journal, 31, 387-406. https://doi.org/10.1046/j.1365-313X.2002.01366.x

[54] Tripolskaja, L. (1999) Agrocheminių priemonių naudojimo aspektai lengvos granuliometrinès sudèties dirvožemiuose pietryčių Lietuvoje. Žemdirbystė, 66, 27-35.

[55] Price, P.W., Bouton, C.E., Gross, P., McPheron, B.A., Thompson, J.N. and Weis, A.E. (1980) Interactions among Three Trophic Levels: Influence of Plants on Interactions between Herbivores and Natural Enemies. Annual Review of Ecology and Systematics, 11, 41-65. https://doi.org/10.1146/annurev.es.11.110180.000353

[56] Soler, R., Van der Putten, W.H. and Harvey, J.A. (2012) Root Herbivore Effects on Aboveground Multitrophic Interactions: Patterns, Processes and Mechanisms. Journal of Chemical Ecology, 38, 755. https://doi.org/10.1007/s10886-012-0104-Z

[57] Stilling, P. and Moon, D.C. (2005) Quality or Quantity: The Direct and Indirect Effects of Host Plants on Herbivores and Their Natural Enemies. Oecologia, 142, 413-420. https://doi.org/10.1007/s00442-004-1739-4

[58] Tan, Z.Q., Ai, T.C., Lu, X.Z., Cai, Q.N. and Liu, C. (2012) Influences of Soil Fertility on Spatial Patterns of Aphis Gossypii Glover (Homoptera: Aphididae) Occurred in Bt-Cotton Plants. Advance Journal of Food Science and Technology, 4, 377-382.

[59] Thaler, J.S. (1999) Jasmonate-Inducible Plant Defense Caused Parasitism of Herbivores. Nature, 399, 686-688. https://doi.org/10.1038/21420

[60] Verkerk, R.H.J., Leather, S.R. and Wright, D.J. (1998) The Potential for Manipulating Crop-Pest-Natural Enemy Interactions for Improved Insect Pest Management. Bulletin of Entomological Research, 88, 493-501. https://doi.org/10.1017/S0007485300026018

[61] Warren, P.H. and Gaston, K.J. (1992) Predator-Prey Ratios: A Special Case of a General Pattern? Philosophical Transactions of the Royal Society of London, Series B: Biological Sciences, 338, 113-130. https://doi.org/10.1098/rstb.1992.0135

[62] Ge, G., Li, Z. and Fan, F. (2010) Soil Biological Activity and Their Seasonal Variations in Response to Long-Term Application of Organic and Inorganic Fertilizers. Plant Soil, 326, 31-44. https://doi.org/10.1007/s11104-009-0186-8 
Submit or recommend next manuscript to SCIRP and we will provide best service for you:

Accepting pre-submission inquiries through Email, Facebook, LinkedIn, Twitter, etc. A wide selection of journals (inclusive of 9 subjects, more than 200 journals)

Providing 24-hour high-quality service

User-friendly online submission system

Fair and swift peer-review system

Efficient typesetting and proofreading procedure

Display of the result of downloads and visits, as well as the number of cited articles

Maximum dissemination of your research work

Submit your manuscript at: http://papersubmission.scirp.org/

Or contact as@scirp.org 